\title{
A Study Of The Agriculture Of Poland And Romania In Post-Communist Period
}

\author{
Laurentiu Ivanov, PhD Student \\ Bucharest University of Economic Studies, Romania
}

doi: 10.19044/esj.2016.v12n10p470 URL:http://dx.doi.org/10.19044/esj.2016.v12n10p470

\begin{abstract}
In terms of size of territory and population, Poland and Romania are the largest former socialist countries, now, members of the European Union. In the last 25 years of transition to a market economy, Poland has excellent managed its natural potential and is, now, an economic model for other former socialist countries, including Romania. Poland has not experienced economic recession; its positive economic evolution was completely different from the evolution of the largest European economies, many of them facing distressful situations for long periods of time.

The question to be addressed in this paper is: „How could we explain the present success of Polish agriculture? Could the present economic realities be partially influenced by the historical evolution of a country? " In an attempt to provide an answer to this question, the present paper will highlight the economic developments in Romania and Poland in relation to developed countries for the last about 100 years in terms of "path dependency theory" and will conduct a comparative analysis between the two countries.
\end{abstract}

Keywords: Agriculture, economic development, comparative analysis, Romania, Poland, path dependency

\section{Introduction}

The socialist model of economic and social development, applied with some particuliarities and different results in the countries of Central and Eastern Europe, collapsed at the end of 1989. This happend because the maintaining of the control of socialist countries meant higher costs than the economic, political and military possibilities of USSR .

Thus, in 1989, all communist regimes from Central and Eastern Europe had collapsed and started their post-communist transition toward a political system based on the market economy. The transition to the market economy led to radical structural changes in terms of socio-economic and institutional changes. The amplitude and speed of these changes were 
different from country to country depending on the economic situation of each country and also the political will of the governments in power. The efforts of transition to the market economy has been successful by the accession of Poland (2004) and Romania (2007) at the European Union.

This paper emphasizes the changes that took place in agriculture of Poland and Romania during the transition to a market economy and if these changes where influenced by historical factors.

The aim of this paper is to provide an answer to the question of whether a country's current situation of the agriculture can be explained by means of its historical evolution. We try to come up with an answer to this question by comparatively analyzing Romania and Poland during the postcommunist period and searching for possible causes of their different evolutions so far in their manner of development between the two previous periods: inter-war period and communist period.

The paper is structured as follows:

Chapter 1: provides a general view of the agriculture of Poland and Romania in transition to the market economy

Chapter 2 : briefly analyses of agriculture of the two countries during two previous periods: inter-war period and communist period.

We conclude by accentuating on the peripheral character of Romanian agriculture during the time and a good evolution of Polish agriculture especially in the last 25 years.

\section{Agriculture of Poland and Romania in post-communist period}

At present, the agriculture of Poland and Romania is an important branch of the national economy, emphasized by its share in the economy, a level significantly higher than in the developed countries. In both two countries, agriculture represents between $3-10 \%$ of GDP and $10-40 \%$ of the active labour force, compared to only 2-3\% in Western Europe. Taking into account its importance, agriculture is an essential component of reforms in Romania, in Poland and in other former communist countries, reforms that had as results: "de-collectivisation / land privatization, restructuring and privatization of former socialist agricultural enterprises, liberalization of prices and agricultural markets, privatization of upstream and downstream industries, liberalization prices and agricultural markets, creating a banking system adequate to the financing of agriculture, creation of a legislative and institutional framework compatible with the EU. Romania and Poland have an important agricultural potential compared to the countries in transition, engaging a significant workforce. Compared to developed countries, the high percentage that agriculture records in the GDP of Romania and Poland reveals the importance of this sector in the national economy. 
Tab 1: Importance of agriculture in the national economy in several European countries

\begin{tabular}{|c|c|c|c|c|c|c|c|c|c|c|}
\hline & \multicolumn{9}{|c|}{ Share of agriculture in GDP (\%) } & \multicolumn{4}{c|}{ agriculture } \\
\hline Year & France & Poland & Romania & Spain & Hungary & France & Poland & Romania & Spain & Hungary \\
\hline 1990 & 3.50 & $\mathbf{8 . 2 5}$ & $\mathbf{2 1 . 2 0}$ & 5.56 & 14.54 & 5.60 & $\mathbf{2 5 . 2 0}$ & $\mathbf{2 9 . 1 0}$ & 11.80 & 18.20 \\
\hline 1995 & 2.73 & $\mathbf{5 . 2 9}$ & $\mathbf{2 1 . 4 3}$ & 4.21 & 8.42 & 4.90 & $\mathbf{2 2 . 6 0}$ & $\mathbf{4 0 . 3 0}$ & 9.00 & 8.00 \\
\hline 2000 & 2.34 & $\mathbf{3 . 3 0}$ & $\mathbf{1 2 . 0 6}$ & 4.12 & 5.75 & 4.10 & $\mathbf{1 8 . 8 0}$ & $\mathbf{4 2 . 8 0}$ & 6.70 & 6.50 \\
\hline 2004 & 2.02 & $\mathbf{3 . 7 0}$ & $\mathbf{1 4 . 6 0}$ & 3.41 & 5.08 & 3.90 & $\mathbf{1 8 . 0 0}$ & $\mathbf{3 1 . 6 0}$ & 5.50 & 5.30 \\
\hline 2007 & 1.80 & $\mathbf{3 . 4 4}$ & $\mathbf{6 . 4 9}$ & 2.71 & 4.00 & 3.50 & $\mathbf{1 4 . 7 0}$ & $\mathbf{2 9 . 5 0}$ & 4.50 & 4.70 \\
\hline 2011 & 1.84 & $\mathbf{3 . 2 6}$ & $\mathbf{7 . 4 8}$ & 2.46 & 4.65 & 2.90 & $\mathbf{1 2 . 7 0}$ & $\mathbf{2 8 . 6 0}$ & 4.20 & 4.80 \\
\hline 2012 & 1.85 & $\mathbf{3 . 2 1}$ & $\mathbf{6 . 0 1}$ & 2.44 & 4.54 & 2.90 & $\mathbf{1 2 . 6 0}$ & $\mathbf{2 9 . 0 0}$ & 4.40 & 5.20 \\
\hline
\end{tabular}

Source: world bank data

The evolution of agriculture in the GDP in Romania was determined by the regression of other fields of the economy, mainly in industry and certainly not of increasing of agricultural production. The Romanian agriculture recovery after $19 ` 90$ was a long term process with many obstacles because of adoption of some controversial political decisions in the early years of transition to a market economy. These decisions brought among others to a low level of foreign investments and the lack of adequate measures to reform Romania's economy.

In Poland, the labour force employed in agriculture has seen significant reductions in the entire period of transition, going from $25.20 \%$ in 1990 to $12.60 \%$ in 2012. However, if we compare the share of the workforce employed in Polish agriculture to that of developed countries, we can conclude that this indicator is an obstacle in the development of agriculture and of rural areas. Regarding Romania, workforce employed in agriculture increased from $29.10 \%$ in 1990 to $42.80 \%$ in 2000 and decreased to $29,00 \%$ in 2012, being a limiting factor in agricultural recovery. Thus, on the entire transition period, agriculture has become an employment buffer, taking especially layoffs in the industry, becoming a haven of economic and social security for the unemployed who are residing in rural areas and and those who have returned to the countryside after 1990.

Regarding the agricultural areas, both Romania and Poland hold important ones, from this point of view being the most important countries in Central and Eastern EU membership.

Tab 2: Used agricultural area and its share in total area:

\begin{tabular}{|c|c|c|c|c|}
\hline \multirow{2}{*}{ Year } & \multicolumn{2}{|c|}{ Romania } & \multicolumn{2}{c|}{ Poland } \\
\cline { 2 - 5 } & thousand ha & \% & thousand ha & \% \\
\hline 1994 & $14,798.00$ & 62.07 & $18,450.00$ & 59.01 \\
\hline 1998 & $14,802.00$ & 62.09 & $18,229.00$ & 58.30 \\
\hline 2000 & $14,856.80$ & 62.32 & $17,812.30$ & 56.97 \\
\hline 2004 & $14,711.60$ & 61.71 & $16,327.40$ & 52.22 \\
\hline 2007 & $14,709.30$ & 61.70 & $16,177.10$ & 51.74 \\
\hline 2011 & $14,590.90$ & 60.95 & $15,133.90$ & 48.40 \\
\hline
\end{tabular}

Source: INS (2005), INS (2012), GUS (2013) 
Interesting is the analysis in terms of arable land per capita. In 2011, the situation was as follows:

Tab. 3: Gaps in the use of labour in the agricultural sector in 2011

\begin{tabular}{|l|r|r|r|}
\hline & \multicolumn{1}{|c|}{$\begin{array}{c}\text { Surface used in } \\
\text { agriculture (thousand ha) }\end{array}$} & $\begin{array}{c}\text { Employment in } \\
\text { agriculture (thousand) }\end{array}$ & $\begin{array}{c}\text { Area/agriculteral worker } \\
\text { (ha) }\end{array}$ \\
\hline Rountry & $14,590.00$ & $2,612.00$ & 5.59 \\
\hline Poland & $15,133.90$ & $2,376.70$ & 6.37 \\
\hline
\end{tabular}

Source: INS (2012), GUS (2013)

In the year 2011, the agricultural land area/Polish farmer was 6.37 ha, better than 5.59 ha agricultural land area/Romanian farmer. In 2000, this indicator was $6.80 \mathrm{ha} /$ farmer in Poland and only $3.04 \mathrm{ha} /$ farmer in Romania. The level of this indicator in the EU (15 members) in the same period of time (2000) was 19.30 ha / farmer. Although there is an improvement of this indicator, the gap with the average of EU is still very large. In order to ensure a level of labour productivity similar to that of developed European countries, both in Poland and especially in Romania, it requires significant reduction of the surplus labour force employed in agriculture, the technical modernization of production, a real concentration of capital land, setting up competitive production units and increasing the value of work as a result of revenue growth in agriculture. Interesting is the picture of the main productions in post-communist period:

Tab. 4: Wheat production in several European countries (thousand tons)

\begin{tabular}{|l|r|r|r|r|r|r|r|}
\hline & $\mathbf{1 9 8 9}$ & $\mathbf{1 9 9 5}$ & $\mathbf{2 0 0 0}$ & $\mathbf{2 0 0 4}$ & $\mathbf{2 0 0 7}$ & $\mathbf{2 0 1 0}$ & $\mathbf{2 0 1 3}$ \\
\hline Bulgaria & $5,425.00$ & $3,435.30$ & $3,406.30$ & $3,961.20$ & $2,390.60$ & $4,094.60$ & $5,504.90$ \\
\hline Greece & $2,763.00$ & $2,139.00$ & $1,858.00$ & $1,773.70$ & $1,383.50$ & $1,663.10$ & $1,585.60$ \\
\hline Spain & $5,468.70$ & $3,138.70$ & $7,293.60$ & $7,096.70$ & $6,436.40$ & $5,941.20$ & $7,744.80$ \\
\hline France & $31,821.10$ & $30,868.30$ & $37,353.40$ & $39,692.90$ & $32,769.90$ & $38,194.70$ & $38,637.50$ \\
\hline Hungary & $6,540.00$ & $4,614.00$ & $3,692.50$ & $6,006.80$ & $3,986.70$ & $3,763.70$ & $5,058.30$ \\
\hline Austria & $1,361.50$ & $1,301.40$ & $1,313.00$ & $1,718.80$ & $1,399.30$ & $1,517.80$ & $1,597.70$ \\
\hline Poland & $8,461.60$ & $8,668.00$ & $8,502.90$ & $9,892.50$ & $8,317.30$ & $9,487.80$ & $9,485.20$ \\
\hline Romania & $7,845.70$ & $7,666.60$ & $4,434.40$ & $7,812.40$ & $3,044.50$ & $5,587.50$ & $7,296.40$ \\
\hline Slovakia & $2,266.40$ & $1,937.90$ & $1,254.30$ & $1,764.80$ & $1,379.60$ & $1,227.80$ & \\
\hline
\end{tabular}

Source: Eurostat data

As it can be noticed, the evolution of the Romanian wheat production are extremely sensitive to the variations in weather and natural conditions. Far more revealing are the yields per hectare. 
Tab 5: Average production of wheat per hectare in various European countries (quintals / hectare)

\begin{tabular}{|l|r|r|r|r|r|r|r|}
\hline & $\mathbf{1 9 9 0}$ & $\mathbf{1 9 9 5}$ & $\mathbf{2 0 0 0}$ & $\mathbf{2 0 0 4}$ & $\mathbf{2 0 0 7}$ & $\mathbf{2 0 1 2}$ & $\mathbf{2 0 1 3}$ \\
\hline EU & 58.30 & 59.70 & 58.60 & 58.90 & 48.40 & 51.10 & $:$ \\
\hline Bulgaria & 45.50 & 29.10 & 30.80 & 38.90 & 22.10 & 37.60 & 42.50 \\
\hline Greece & 19.30 & 25.00 & 22.30 & 21.20 & 22.20 & 27.90 & $:$ \\
\hline Spain & 23.80 & 14.80 & 31.00 & 32.60 & 35.70 & 23.70 & 35.80 \\
\hline France & 64.80 & 65.10 & 71.20 & 75.80 & 62.60 & 66.10 & 72.50 \\
\hline Hungary & 50.80 & 41.60 & 36.10 & 51.20 & 35.90 & 37.50 & 46.20 \\
\hline Austria & 50.50 & 50.90 & 44.70 & 59.20 & 47.80 & 41.40 & 53.70 \\
\hline Poland & $\mathbf{3 9 . 6 0}$ & $\mathbf{3 6 . 0 0}$ & $\mathbf{3 2 . 3 0}$ & $\mathbf{4 2 . 8 0}$ & $\mathbf{3 9 . 4 0}$ & $\mathbf{4 1 . 4 0}$ & $\mathbf{4 4 . 3 0}$ \\
\hline Romania & $\mathbf{3 2 . 4 0}$ & $\mathbf{3 0 . 9 0}$ & $\mathbf{2 2 . 9 0}$ & $\mathbf{3 4 . 0 0}$ & $\mathbf{1 5 . 4 0}$ & $\mathbf{2 6 . 1 0}$ & $\mathbf{3 4 . 8 0}$ \\
\hline Slovakia & 50.00 & $\mathbf{4 4 . 4 0}$ & 30.90 & $\mathbf{4 7 . 8 0}$ & 38.30 & 32.90 & $:$ \\
\hline Turkey & & & 22.30 & 22.60 & 21.30 & 26.70 & $:$ \\
\hline
\end{tabular}

Source: Eurostat data

It can be seen the maintaining of the gap in terms of yields per hectare recorded in Romania compared to developed countries and to the neighbouring countries. For example, the yields per hectare are considered modest if you really consider the existing potential of Romania: we obtain a multi-annual average production of wheat of approximately $2000 \mathrm{~kg}$ (compared to $5500-7000 \mathrm{~kg}$ as potential) and maize of about $3000 \mathrm{~kg}$ per hectare (compared to $8000 \mathrm{~kg}$, potential). These productions of wheat and maize but also of other vegetable products, whether expressed to population, it ranks Romania to the limit of insuring its safety and food autonomy.

The responses of this evolution cannot be placed mainly only on account of weather. Other more serious factors are:

-the excessive fragmentation of holdings through the repossession of former owners and their descendants

-the destroying of the investments made during the communist era, which would have contributed to a higher production.

-the low agrotechnic level.

Regarding the low agrotechnic level, it could be emphasized by the number of tractors per 100 square kilometers of arable land in Poland, Romania and other European countries. 
Tab. 6: Evolution of the number of tractors since 1990 in several European countries (number of tractors per 100 square kilometers of arable land)

\begin{tabular}{|l|r|r|r|r|r|r|}
\hline Country & $\mathbf{1 9 9 0}$ & $\mathbf{1 9 9 5}$ & $\mathbf{2 0 0 0}$ & $\mathbf{2 0 0 4}$ & $\mathbf{2 0 0 7}$ & $\mathbf{2 0 0 8}$ \\
\hline Austria & $2,373.65$ & $2,517.81$ & $2,394.77$ & $2,397.03$ & & \\
\hline Bulgaria & 135.83 & 95.80 & 98.44 & 93.46 & 149.90 & 172.29 \\
\hline Spain & 483.10 & 573.58 & 671.42 & 742.11 & 807.28 & 825.14 \\
\hline UK & 791.91 & 762.29 & 772.39 & 696.89 & & \\
\hline France & 800.04 & 716.38 & 685.47 & 652.89 & & \\
\hline Greece & 744.24 & 837.28 & 925.88 & 983.17 & & \\
\hline Hungary & 97.74 & 191.84 & 246.21 & 258.90 & & \\
\hline Poland & $\mathbf{8 2 3 . 6 0}$ & $\mathbf{9 2 8 . 4 9}$ & $\mathbf{9 3 3 . 8 2}$ & $\mathbf{1 , 0 8 2 . 7 9}$ & $\mathbf{1 , 2 4 2 . 5 1}$ & $\mathbf{1 , 2 4 5 . 9 9}$ \\
\hline Portugal & 563.14 & 697.11 & $1,040.50$ & $1,139.56$ & & \\
\hline Romania & $\mathbf{1 4 0 . 6 2}$ & $\mathbf{1 7 4 . 9 7}$ & $\mathbf{1 7 0 . 6 1}$ & $\mathbf{1 9 2 . 7 2}$ & $\mathbf{2 0 0 . 5 8}$ & $\mathbf{2 0 0 . 4 2}$ \\
\hline Slovakia & & 178.20 & 153.66 & 158.31 & 153.83 & 154.65 \\
\hline Turkey & 279.81 & 315.11 & 395.30 & & & 103.31 \\
\hline Ukraine & & 140.99 & 97.93 & 114.03 & 103.86 & 103 \\
\hline
\end{tabular}

Source: world bank data

We notice the small number of tractors, available in Romania compared to the European average (without to take into consideration their obsolete technical status, resulting from the financial inability of smallholders to buy other new equipments). On this indicator, Poland recorded higher values than the European average. In addition, it is undoubtedly that, very small holdings are not not proper to become modern forms of exploitation of agriculture because of the absence of seed selection, improper storage of crops, lack of know-how regarding crop rotation , lack of large-scale irrigation etc.

Regarding the use of fertilizers in farming Romania's situation is also a bad one, Romania being ranked on the last places. In Poland, the situation is completely different, being superior even than the European average.

Tab. 7: Quantity of fertilizers used in Romania and other countries(kg/ha)

\begin{tabular}{|l|r|r|r|r|r|r|r|r|r|r|}
\hline Country & $\mathbf{2 0 0 2}$ & $\mathbf{2 0 0 3}$ & $\mathbf{2 0 0 4}$ & $\mathbf{2 0 0 5}$ & $\mathbf{2 0 0 6}$ & $\mathbf{2 0 0 7}$ & $\mathbf{2 0 0 8}$ & $\mathbf{2 0 0 9}$ & $\mathbf{2 0 1 0}$ & $\mathbf{2 0 1 1}$ \\
\hline Austria & 234.02 & 295.65 & 130.71 & 135.10 & 130.15 & 109.79 & 109.64 & 83.14 & 108.15 & 103.13 \\
\hline Bulgaria & 113.77 & 147.33 & 80.85 & 74.23 & 73.94 & 102.01 & 111.24 & 104.60 & 97.05 & 133.08 \\
\hline Spain & 164.45 & 175.27 & 165.40 & 142.14 & 142.33 & 157.72 & 106.54 & 96.93 & 130.68 & 122.62 \\
\hline EU & 166.61 & 174.36 & 168.00 & 160.18 & 156.82 & 168.02 & 137.79 & 124.14 & 146.69 & 142.90 \\
\hline France & 211.30 & 223.36 & 212.10 & 192.49 & 190.39 & 209.34 & 152.53 & 120.56 & 150.54 & 141.29 \\
\hline Greece & 156.38 & 162.09 & 176.42 & 143.04 & 124.63 & 96.90 & 119.05 & 62.99 & 123.70 & 120.15 \\
\hline Hungary & 94.88 & 95.50 & 98.52 & 85.20 & 99.20 & 110.41 & 96.70 & 77.48 & 84.33 & 93.29 \\
\hline Poland & $\mathbf{1 1 6 . 2 0}$ & $\mathbf{1 2 8 . 8 7}$ & $\mathbf{1 2 9 . 1 4}$ & $\mathbf{1 6 1 . 9 4}$ & $\mathbf{1 5 9 . 3 4}$ & $\mathbf{1 7 1 . 3 3}$ & $\mathbf{1 5 1 . 0 9}$ & $\mathbf{1 4 1 . 7 1}$ & $\mathbf{1 7 8 . 9 4}$ & $\mathbf{1 6 9 . 7 4}$ \\
\hline Portugal & 194.04 & 176.96 & 208.31 & 207.12 & 135.29 & 209.44 & 161.61 & 119.38 & 152.29 & 145.18 \\
\hline Romania & $\mathbf{3 4 . 7 8}$ & $\mathbf{3 8 . 6 3}$ & $\mathbf{4 2 . 6 3}$ & $\mathbf{5 1 . 3 5}$ & $\mathbf{4 0 . 6 0}$ & $\mathbf{4 4 . 6 4}$ & $\mathbf{4 5 . 6 4}$ & $\mathbf{4 8 . 4 9}$ & $\mathbf{5 2 . 5 5}$ & $\mathbf{5 4 . 1 3}$ \\
\hline Serbia & & & & & 117.39 & 153.66 & 114.56 & 143.52 & 116.44 & 126.84 \\
\hline Slovakia & 83.11 & 78.95 & 83.67 & 80.50 & 91.78 & 89.95 & 75.08 & 78.31 & 85.06 & 95.94 \\
\hline Slovenia & 403.48 & 400.29 & 358.70 & 329.55 & 322.01 & 324.53 & 285.14 & 246.19 & 287.44 & 279.67 \\
\hline Turkey & 72.80 & 84.29 & 85.63 & 86.76 & 91.84 & 90.34 & 71.97 & 104.57 & 96.38 & 102.86 \\
\hline Ukraine & 15.95 & 15.78 & 16.42 & 17.19 & 21.55 & 27.64 & 32.79 & 27.30 & 32.66 & 38.87 \\
\hline
\end{tabular}

Source: world bank data 
Regarding the production of industrial plants, Romania's situation is better both in relation to Poland and other European countries:

Tab. 8: Production of industrial plants in Romania and several European countries (thousand tons)

\begin{tabular}{|l|l|r|r|r|r|r|r|}
\hline & $\mathbf{1 9 9 0}$ & $\mathbf{1 9 9 5}$ & $\mathbf{2 0 0 0}$ & $\mathbf{2 0 0 4}$ & $\mathbf{2 0 0 7}$ & $\mathbf{2 0 1 0}$ & $\mathbf{2 0 1 3}$ \\
\hline Bulgaria & $:$ & $:$ & 690.80 & $1,279.90$ & 742.8 & $2,201.10$ & $2,396.40$ \\
\hline Greece & $:$ & $:$ & $:$ & $:$ & $:$ & 967.40 & $:$ \\
\hline Spain & $:$ & $:$ & $1,420.00$ & $1,495.20$ & 873.3 & $1,088.50$ & $1,381.10$ \\
\hline France & $:$ & $5,541.20$ & $6,185.10$ & $6,480.00$ & & $10,142.10$ & $9,136.80$ \\
\hline Hungary & $:$ & $:$ & $:$ & $1,600.70$ & 1,663 & $1,649.90$ & $:$ \\
\hline Austria & $:$ & $:$ & $:$ & $:$ & 274.5 & 375.30 & 358.50 \\
\hline Poland & $\mathbf{1 , 4 0 9 . 4 0}$ & $\mathbf{1 , 4 9 8 . 0 0}$ & $\mathbf{1 , 0 7 3 . 2 0}$ & $\mathbf{1 , 7 9 1 . 6 0}$ & $\mathbf{2 , 2 8 2 . 4}$ & $\mathbf{2 , 3 6 4 . 8 0}$ & $\mathbf{2 , 7 8 4 . 2 0}$ \\
\hline Portugal & $:$ & 32.30 & 34.70 & 19.30 & 15.5 & 8.60 & $:$ \\
\hline Romania & $\mathbf{9 0 9 . 8 0}$ & $\mathbf{1 , 1 0 7 . 1 0}$ & $\mathbf{8 9 0 . 7 0}$ & $\mathbf{2 , 0 2 6 . 5 0}$ & $\mathbf{2}$ & $\mathbf{2 , 3 7 4 . 6 0}$ & $\mathbf{2 , 9 7 8 . 8 0}$ \\
\hline Slovakia & 167.20 & 259.40 & 264.80 & 494.80 & 470.7 & 501.80 & 615.20 \\
\hline Albania & 50.00 & 8.20 & 9.70 & 4.70 & 3.7 & 4.80 & $:$ \\
\hline Serbia & $:$ & $:$ & $:$ & $:$ & $:$ & $:$ & $:$ \\
\hline Turkey & $:$ & $:$ & $4,464.70$ & $:$ & $3,182.6$ & $:$ & $3,403.00$ \\
\hline
\end{tabular}

Source: Eurostat data

Regarding animal agricultural production in the last 25 years, the livestock met a totally unfavorable evolution both in Poland and Romania . In the case of Romania, there was a dramatic drop in livestock through forced slaughters, high mortality, export improperly done (only in 1992 there were exported about two million cattle). There were destroyed modern industrial enterprises of growing high-yield livestock and poultry.

Tab. 9: Evolution herd of cattle in Romania and several European countries (thousand heads)

\begin{tabular}{|c|c|c|c|c|c|c|c|}
\hline Country & 1990 & 1995 & 2000 & 2004 & 2007 & 2010 & 2013 \\
\hline EU (27) & • & & & & $89,431.47$ & $87,387.19$ & $87,187.12$ \\
\hline Bulgaria & $1,482.00$ & 645.00 & 652.20 & 679.55 & 611.02 & 553.70 & 585.55 \\
\hline Greece & 687.13 & 550.00 & 568.00 & 640.00 & 682.00 & 679.00 & 653.00 \\
\hline Spain & $5,104.11$ & $5,495.00$ & $6,163.89$ & $6,653.09$ & $6,584.98$ & $6,075.08$ & $5,696.91$ \\
\hline France & $21,446.00$ & $20,836.50$ & $20,088.93$ & $18,948.00$ & $19,124.00$ & $19,599.00$ & $19,129.00$ \\
\hline Hungary & $1,571.00$ & 928.00 & 805.00 & 723.00 & 705.00 & 682.00 & 782.00 \\
\hline Austria & & $2,325.83$ & $2,155.45$ & $2,050.99$ & $2,000.20$ & $2,013.28$ & $1,958.28$ \\
\hline Poland & $9,024.20$ & $7,193.00$ & $5,723.00$ & $5,200.17$ & $5,405.55$ & $5,561.75$ & $5,589.54$ \\
\hline Portugal & $1,367.00$ & $1,386.41$ & $1,396.86$ & $1,488.15$ & $1,491.50$ & $1,502.76$ & $1,470.50$ \\
\hline Romania & $5,381.00$ & $3,496.30$ & $2,870.40$ & $2,808.10$ & $2,819.00$ & $2,001.10$ & $2,022.40$ \\
\hline Slovakia & $1,563.00$ & 929.00 & 646.15 & 540.15 & 501.82 & 467.13 & 467.82 \\
\hline Serbia & (1) & 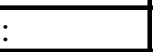 & & : & $1,087.00$ & 938.00 & 913.00 \\
\hline Turkey & & & & & & & $14,532.85$ \\
\hline
\end{tabular}

Source: Eurostat data 
Tab. 10: Evolution of livestock in Romania and Poland between 1990 and 2013 (thousand heads)

\begin{tabular}{|l|r|r|r|r|r|r|}
\hline Country & \multicolumn{3}{|c|}{ Romania } & \multicolumn{3}{|c|}{ Poland } \\
\hline & $\mathbf{1 9 9 0}$ & $\mathbf{2 0 1 3}$ & $\mathbf{2 0 1 3 / 1 9 9 0}$ & $\mathbf{1 9 9 0}$ & $\mathbf{2 0 1 3}$ & $\begin{array}{r}\text { (2013/1990 } \\
\end{array}$ \\
\hline Cattle & $5,381.00$ & $2,022.40$ & -62.42 & $9,024.20$ & $5,589.54$ & -38.06 \\
\hline Swine & $12,003.00$ & $5,180.20$ & -56.84 & $19,739.20$ & $10,994.40$ & -44.30 \\
\hline Sheep & $14,062.00$ & $9,135.60$ & -35.03 & $3,798.00$ & 218.51 & -94.25 \\
\hline Goats & $1,005.00$ & $1,313.00$ & 30.65 & & & \\
\hline
\end{tabular}

Source: Eurostat data

The low levels of livestock in Romania can be highlighted by expressing the density of animals to 100 hectares (agricultural land and pastures). For example, in 2012, on the density of cattle and on density of swine, Romania was ranked on the last places.

Tab. 11: Density of cattle in the EU countries at the level of 2012 (thousand heads)

\begin{tabular}{|l|r|r|l|r|r|}
\hline Country & $\begin{array}{l}\text { livestock } \\
\text { (thousand } \\
\text { heads) }\end{array}$ & $\begin{array}{l}\text { density } \\
\text { (heads / 100 } \\
\text { hectares) }\end{array}$ & Country & $\begin{array}{l}\text { livestock } \\
\text { (thousand } \\
\text { heads) }\end{array}$ & $\begin{array}{l}\text { density } \\
\text { (heads / 100 } \\
\text { hectares) }\end{array}$ \\
\hline Holland & $4,090.00$ & 227.70 & Italy & $6,249.30$ & 40.70 \\
\hline Belgium & $2,441.30$ & 186.10 & Poland & $5,595.50$ & 39.70 \\
\hline Irland & $6,309.10$ & 139.20 & Finland & 903.40 & 39.60 \\
\hline Slovenia & 460.60 & 101.70 & Czech & $1,332.10$ & 38.20 \\
\hline Germany & $12,686.00$ & 77.00 & Spain & $5,688.80$ & 30.20 \\
\hline Austria & $1,958.30$ & 70.00 & Lithuania & 713.50 & 25.40 \\
\hline France & $19,129.00$ & 68.70 & Slovakia & 467.90 & 25.00 \\
\hline Denmark & $1,583.00$ & 59.70 & Greece & 679.00 & 24.40 \\
\hline UK & $9,682.00$ & 56.50 & Hungary & 772.00 & 15.20 \\
\hline Portugal & $1,470.50$ & 51.30 & Romania & $\mathbf{2 , 0 2 2 . 4 0}$ & $\mathbf{1 4 . 9 0}$ \\
\hline Sweden & $1,443.50$ & 47.70 & Bulgaria & 593.70 & 12.00 \\
\hline
\end{tabular}

Source: INS (2013)

Note: Data for Romania are for the year 2013 UK are for 2011 for the other EU countries are for the year 2012 
Tab. 12: Density of swine population in the EU countries at the level of 2012 (thousand heads)

\begin{tabular}{|l|r|r|l|r|r|}
\hline Country & $\begin{array}{l}\text { livestock } \\
\text { (thousand } \\
\text { heads) }\end{array}$ & $\begin{array}{l}\text { density (heads } \\
\text { / 100 hectares) }\end{array}$ & Country & $\begin{array}{l}\text { livestock } \\
\text { (thousand } \\
\text { heads) }\end{array}$ & $\begin{array}{l}\text { density (heads } \\
\text { / 100 hectares) }\end{array}$ \\
\hline Holland & $12,013.00$ & $1,200.10$ & UK & $4,383.00$ & 72.20 \\
\hline Belgium & $6,351.30$ & 789.50 & Greece & $1,077.00$ & 69.10 \\
\hline Denmark & $12,402.00$ & 509.20 & Hungary & $2,935.00$ & 68.00 \\
\hline Germany & $28,046.10$ & 237.00 & Italy & $8,561.90$ & 66.40 \\
\hline Austria & $2,895.80$ & 213.70 & Czech & $1,547.70$ & 61.40 \\
\hline Spain & $25,654.40$ & 204.90 & Romania & $\mathbf{5 , 1 8 0 . 2 0}$ & $\mathbf{5 8 . 9 0}$ \\
\hline Portugal & $2,020.30$ & 188.80 & Sweden & $1,478.20$ & 57.00 \\
\hline Slovenia & 303.60 & 176.90 & Finland & $1,258.30$ & 56.00 \\
\hline Irland & $1,468.50$ & 125.60 & Slovakia & 637.00 & 46.80 \\
\hline Poland & $\mathbf{1 0 , 9 9 4 . 4 0}$ & $\mathbf{1 0 1 . 1 0}$ & Lithuania & 754.30 & 33.40 \\
\hline France & $13,428.00$ & 73.10 & Bulgaria & 588.50 & 17.90 \\
\hline
\end{tabular}

Source: INS (2013)

Note: Data for Romania are for the year 2013, for UK are for 2011 and for the other EU countries are for the year 2012

We could put the question: the recent developments of agriculture in Poland and Romania could be explained from an historical perspective?

In order to find an answer, we have to analyze the evolution of agriculture of Poland and Romania in previous periods: inter-war and communism.

\section{The agriculture of Poland and Romania during two periods: inter- war period and communist period.}

\subsection{The agriculture of Poland and Romania in the interwar period}

Extending the analysis of the evolution of Polish and Romanian agriculture, beginning 1918, we notice that, permanently, the both countries have been in a race of tracking the evolution in developed countries. In this race, Poland had better results.

Taking into account the information regarding their natural, human and economically productive potential, Romania and Poland were situated in the inter-war period among the first countries in Europe, but from the point of view of the economic and social development level, their status was fundamentally different compared to their potential status.

Despite of all efforts, in the interwar period, the Romanian and Polish agriculture had to endure the consequences of their own underdevelopment and additionally, effects of the world economic crisis (for example: the world agrarian crisis during 1928-1936). Regarding the development of agriculture, we may unquestionably say that at the end of the inter-war period, Romania had not really started the restructuring its agricultural production. This reality 
was reflected in a low level of the Romanian agricultural productivity, which in 1938 was of only 80 dollars/person in agriculture, as opposed to 130 dollars/person in Poland, 200 dollars/ person in Czechoslovakia or 560 dollars / person in Great Britain (Dobre, 1996).

Tab. 13: Agricultural productivity (\$/person) in European countries, 1938

\begin{tabular}{|c|c|}
\hline Country & Dollars/person in agriculture \\
\hline Great Britain & 560 \\
\hline Netherlands & 500 \\
\hline Sweden & 470 \\
\hline Denmark & 440 \\
\hline Switzerland & 430 \\
\hline Belgium and Luxembourg & 400 \\
\hline Ireland & 310 \\
\hline Germany & 290 \\
\hline France & 280 \\
\hline Czechoslovakia & 200 \\
\hline Norway & 200 \\
\hline Austria & 160 \\
\hline Hungary & 150 \\
\hline Italy & 130 \\
\hline Poland & $\mathbf{1 3 0}$ \\
\hline Finland & 110 \\
\hline Bulgaria & 110 \\
\hline Romania & $\mathbf{8 0}$ \\
\hline Average of the 18 European countries & 210 \\
\hline
\end{tabular}

Source: Dobre (1996)

The international comparisons outlines very well the deepening backwardness of the level of the Romanian agricultural productivity, even the average production of wheat / ha, the Romanian main agricultural product.

Tab. 14: Average production of wheat per hectare in various European countries (quintals / hectare, rounded figures)

\begin{tabular}{|l|c|c|c|}
\hline Country & $\mathbf{1 9 0 8 - 1 9 1 2}$ & $\mathbf{1 9 2 0 - 1 9 2 2}$ & $\mathbf{1 9 3 4 - 1 9 3 8}$ \\
\hline Romania & $\mathbf{1 1 . 7}$ & $\mathbf{8 . 9}$ & $\mathbf{1 0 . 3}$ \\
\hline Denmark & 31.0 & 29.0 & 30.4 \\
\hline UK & 21.4 & 20.0 & 23.1 \\
\hline Germany & 18.5 & 17.0 & 22.0 \\
\hline Czechoslovakia & $\ldots \ldots$ & 15.0 & 17.1 \\
\hline Austria & $\ldots \ldots$ & 11.0 & 16.7 \\
\hline France & 13.2 & 14.0 & 15.6 \\
\hline Italy & 9.6 & 10.0 & 14.4 \\
\hline Hungary & $\ldots \ldots$ & 11.0 & 14.0 \\
\hline Poland & $\ldots \ldots$ & $\mathbf{1 0 . 0}$ & $\mathbf{1 4 . 6}$ \\
\hline Serbia/ Yugoslavia & 10.0 & 10.0 & 11.5 \\
\hline Bulgaria & 10.3 & 12.0 & 12.5 \\
\hline Grecia & 7.0 & 7.0 & 9.0 \\
\hline Spania & 9.4 & 9.0 & 9.6 \\
\hline Portugal & 6.0 & 10.0 & 9.0 \\
\hline
\end{tabular}

Source: Murgescu (2011) 
This case can highlight a very important conclusion, namely the average yields per hectare on the whole period were under the pre-war yields. (Murgescu, 2011) It can be seen that the lower yields per hectare led not only to increasing of the productivity gap with the developed countries of Europe, but also with the predominantly agricultural countries neighbouring Romania (Bulgaria, Yugoslavia, Hungary, Poland).

\subsection{The agriculture of Poland and Romania during the communist period}

For a first analysis of the performance of Romania and Poland after the war, it is worth to emphasize the evolution of GDP / capita in the period 1950- 1989:

Tab. 15: Evolution of GDP/capita (PPP) in Romania, Poland and Europe (1938-1989) (1990 international Geary-Khamis dollars) ${ }^{1}$

\begin{tabular}{|c|c|c|c|c|c|c|}
\hline & Romania & Poland & $\begin{array}{c}\text { 7 East } \\
\text { European } \\
\text { Countries }\end{array}$ & $\begin{array}{c}\text { Average of 36 } \\
\text { West } \\
\text { European } \\
\text { Countries }\end{array}$ & $\begin{array}{c}\text { Romanıa } \\
\text { compared to } \\
\text { European } \\
\text { average }\end{array}$ & $\begin{array}{c}\text { Poland } \\
\text { compared to } \\
\text { European } \\
\text { average }\end{array}$ \\
\hline 1938 & 1,242 & 2,182 & 1,764 & 3,226 & 0.38 & 0.68 \\
\hline 1950 & 1,182 & 2,447 & 2,111 & 3,655 & 0.32 & 0.67 \\
\hline 1960 & 1,844 & 3,215 & 3,070 & 5,316 & 0.35 & 0.60 \\
\hline 1970 & 2,853 & 4,428 & 4,315 & 7,697 & 0.37 & 0.58 \\
\hline 1980 & 4,135 & 5,740 & 5,786 & 9,643 & 0.43 & 0.60 \\
\hline 1989 & 3,941 & 5,684 & 5,915 & 11,113 & 0.35 & 0.51 \\
\hline
\end{tabular}

Source: Maddison (2003) and own calculation

Above data, outlines the increasing gap Romania, Poland compared both the European average (which was expected) and to other eastern European countries. The developments of two countries were mainly similar; however, after the war, Romania has suffered effects of war more than Poland (and to the other socialist countries), then Romania has seen a high growth of about three decades (above the European average), followed by a last disastrous decade in terms economic development. Regarding the evolution of Romania and Poland in this last "socialist decade", is it useful to compare the performance of different socialist countries.

Interesting is the analysis of performances of Romania and Poland in agriculture and a first indicator in this regard is the labor productivity in agriculture (see Table 16).

\footnotetext{
${ }^{1}$ Average of \& East European countries: Albania, Bulgaria, Czechoslovakia (or Czech Republic and Slovakia), Hungary, Poland Romania, Yugoslavia (or former Yugoslavian area).
} 
Tab. 16: Agricultural productivity in Romania and Poland and other European countries in the period 1948 / 52-1988 / 92 (millions of calories produced by a male agricultural worker)

\begin{tabular}{|l|c|c|c|c|c|}
\hline Country & $\mathbf{1 9 4 8 / 5 2}$ & $\mathbf{1 9 5 8 / 6 2}$ & $\mathbf{1 9 6 8} / \mathbf{7 2}$ & $\mathbf{1 9 7 8 / 8 2}$ & $\mathbf{1 9 8 8 / 9 2}$ \\
\hline Austria & 15.2 & 35.0 & 56.2 & 94.7 & 117.9 \\
\hline Bulgaria & 12.5 & 22.3 & 49.2 & 89.5 & 117.3 \\
\hline Czechoslovakia & 21.8 & 35.5 & 52.7 & 73.2 & 91.3 \\
\hline France & 22.3 & 40.8 & 64.8 & 120.2 & 187.3 \\
\hline Germany (FRG) & 31.8 & 59.7 & 106.7 & 183.9 & 240.6 \\
\hline Greece & 4.5 & 7.0 & 8.6 & 15.0 & 22.3 \\
\hline Irland & 20.9 & 31.3 & 38.6 & 64.9 & 94.8 \\
\hline Italy & 9.2 & 18.4 & 31.2 & 58.1 & 83.2 \\
\hline Yugoslavia & 18.6 & 33.9 & 40.3 & 75.4 & 88.4 \\
\hline UK & 36.6 & 62.1 & 85.1 & 111.7 & 139.7 \\
\hline Poland & $\mathbf{1 9 . 6}$ & $\mathbf{2 8 . 7}$ & $\mathbf{3 5 . 6}$ & $\mathbf{4 0 . 0}$ & $\mathbf{4 5 . 3}$ \\
\hline Portugal & 6.6 & 8.8 & 18.6 & 25.5 & 44.5 \\
\hline Romania & $\mathbf{8 . 6}$ & $\mathbf{1 2 . 5}$ & $\mathbf{2 3 . 2}$ & $\mathbf{5 2 . 9}$ & $\mathbf{5 9 . 2}$ \\
\hline Hungary & 12.3 & 21.6 & 35.9 & 71.3 & 90.7 \\
\hline Soviet Union & 21.3 & 38.3 & 55.8 & 58.8 & 63.4 \\
\hline
\end{tabular}

Source: Murgescu (2011)

The analysis of labor productivity takes into account active males in agriculture, favoring developed countries that use less labor and more capital, and the results could be distorted.

Therefore, in order to have a real view of agricultural productivity, we have to complete our analysis with other data, for example wheat crop yield.

Tab. 17: The yield of wheat crop in Romania and Poland and other European countries in the period 1950-1990 (quintals / ha)

\begin{tabular}{|l|c|c|c|}
\hline Country & $\mathbf{1 9 5 0}$ & $\mathbf{1 9 7 0}$ & $\mathbf{1 9 9 0}$ \\
\hline Austria & 17.1 & 32.8 & 51.5 \\
\hline Bulgaria & 12.4 & 29.3 & 40.0 \\
\hline Czechoslovakia & 19.0 & 32.5 & 51.2 \\
\hline France & 18.3 & 38.3 & 64.1 \\
\hline West Germany & 26.2 & 39.0 & 65.6 \\
\hline Greece & 10.2 & 17.8 & 26.4 \\
\hline Irland & 22.6 & 42.2 & 81.8 \\
\hline Italy & 15.2 & 23.7 & 30.5 \\
\hline Yugoslavia & 11.9 & 24.2 & 41.1 \\
\hline UK & 27.1 & 40.8 & 70.2 \\
\hline Poland & $\mathbf{1 2 . 5}$ & $\mathbf{2 4 . 7}$ & $\mathbf{3 6 . 3}$ \\
\hline Portugal & 7.2 & 10.3 & 15.5 \\
\hline Romania & $\mathbf{1 0 . 2}$ & $\mathbf{1 8 . 8}$ & $\mathbf{3 4 . 2}$ \\
\hline Hungary & 13.8 & 27.1 & 50.1 \\
\hline Soviet Union & 14.7 & 14.3 & 19.2 \\
\hline
\end{tabular}

Source: Murgescu (2011)

Also in this case, the position of Romania and Poland was one peripheral for the entire period 1950-1990: 
Tab. 18: Economic level of Romania and Poland in European context (1989) expressed by other data

\begin{tabular}{|l|c|c|c|}
\hline Country & $\begin{array}{c}\text { Milk yiedd per cow } \\
\text { liters/ head }\end{array}$ & $\begin{array}{c}\text { Number of } \\
\text { tractors/ } \mathbf{1 0 0} \text { ha }\end{array}$ & $\begin{array}{c}\text { Consumption of } \\
\text { fertilizers kg./ ha }\end{array}$ \\
\hline Albania & 1,276 & 1.7 & 137.2 \\
\hline Austria & 3,917 & 22.9 & 210.1 \\
\hline Bulgaria & 3,295 & 1.3 & 221.5 \\
\hline Czechoslovakia & 3,254 & 2.7 & 314.4 \\
\hline France & 2,818 & 7.9 & 313.8 \\
\hline Germany (FRG) & 4,920 & 19.0 & 410.7 \\
\hline Greece & 1,943 & 4.8 & 165.2 \\
\hline Irland & 3,880 & 17.3 & 725.1 \\
\hline Italy & 3,557 & 11.7 & 173.9 \\
\hline Yugoslavia & 1,785 & 14.2 & 130.7 \\
\hline UK & 5,009 & 7.7 & 348.7 \\
\hline Poland & $\mathbf{3 , 3 5 8}$ & $\mathbf{7 . 8}$ & $\mathbf{2 4 5 . 7}$ \\
\hline Portugal & 3,353 & 2.0 & 78.3 \\
\hline Romania & $\mathbf{1 , 9 5 1}$ & $\mathbf{1 . 5}$ & $\mathbf{1 1 7 . 7}$ \\
\hline Hungary & 5,043 & 1.0 & 268.2 \\
\hline Soviet Union & 2,587 & 1.2 & 117.9 \\
\hline $\begin{array}{l}\text { Average of developed } \\
\text { countries }\end{array}$ & $\mathbf{4 , 0 5 7}$ & 9.2 & 247.5 \\
\hline $\begin{array}{l}\text { Average of socialist } \\
\text { countries }\end{array}$ & 2,561 & 3.1 & 133 \\
\hline European average & 3,118 & 3.5 & 157.4 \\
\hline
\end{tabular}

Source: Grigorescu (1993)

The above data confirm peripheral position of Romania (below the average of the former socialist countries) and recorded higher position for Poland (even higher than the European average).

\section{Conclusion:}

Following the conducted research, we can say that the influence of the historical factor plays an important role in all social and economic fields. Due to the lack of complete data series, uniform and reliable, it could not be done an exact quantification of the influence of the historical factor, for the analyzed period (1918- present) but only a quantitative assessment on certain areas. The present status of agriculture of Poland and Romania has deep roots in its historical evolution. In literature, the influence of the historical factor is materialized through the theory of path dependence. The theory of path dependency is rooted in economic history, but it has a relevant contribution latest from Paul David (1985) which explains excellent the existing gap of economic development existing between Western Europe and Central and Eastern Europe, highlighted by the GDP / capita over the last 200 years. 
It is believed that the combination of the geographical factors and historical ones, explains the backwardness in many spheres (political, social, economic) of the countries in Central and Eastern Europe, they being organized in a hinterland of the developed countries in western Europe (Podkaminer 2013).

In conclusion, analyzing the agriculture of Romania and Poland in the last 100 years, we could consider their evolution as similar for first two periods interwar and communism period and an excellent evolution of Polish agriculture after 1990 because of EU funds..

\section{References:}

Academia Romana (2004). Cunoaste Romania. Societatea Romana de Statistica, Fundatia Nationala pentru Stiita si Arta, Editura Economica Academia Romana (2007). Cunoaste Romania. Societatea Romana de Statistica, Fundatia Nationala pentru Stiita si Arta, Editura Economica Aldcroft, D. (2011). The European economy 1914-2000. (4th ed.). London: Routledge.

Axenciuc, V. (1997). Introducere in istoria economica a Romaniei. Epoca moderna. Bucuresti: Editura Fundatiei "Romania de Maine”

Dadak, C. (2012). National Heritage and Economic Policies in Free a Sovereign Poland after 1918. Contemporary European History, 21(2), 193214.

Dobre, Gh. (1996). Economia Romaniei in context european-1938. Bucuresti: Editura Fundatiei Stiintifice "Memoria Oeconomica"

Grigorescu, N. (1993). Nivelul dezvoltarii economico-sociale a Romaniei in context european 1989, Bucuresti, Editura Expert

Hustad, R.V. (1996). Shock therapy and gradualism: East and Central Europe 1990-94. Internasjonal Politikk, 54(4), 469-\&.

Landau, Z. (1985). The Polish economy in the twentieth century. Sydney: Croom Helm

Maddison, A. (2003) The World Economy, Historical Statistics, Paris: Development Center of the OECD

Marin, D. (2001). Economia Romaniei 1990-2000, Bucuresti, Editura Economica

Murgescu, B. (2011). Romania si Europa. Acumularea decalajelor economice (1500-2010). Bucuresti: Editura Polirom

Pascariu, G.C. \& Frunza, R. (2011). Eastern Vs. Southern Peripherality in the EU: The Study from the Perspective of Centre-Periphery Model. Transformations in Business \& Economics, 10(2B-SI), 590-611.

Podkaminer, L. (2013). Development Patterns of Central and East European Countries (in the course of transition and following EU accession), 388 
Report Research- July 2013, The Vienna Institute for International Economic Studies

Prochniak, M. (2011). Determinants of economic growth in Central and Eastern Europe: the global crisis perspective. Post-Communist Economies, 23(4), 449-468

*** INS (2005) Anuarul Statistic al Romaniei

*** INS (2007) Anuarul Statistic al Romaniei

*** INS (2012) Anuarul Statistic al Romaniei

*** Institutul European din Romania (IER), Newsletter IER, nr. 70, Noiembrie 2014. Retrieved from http://www.ier.ro/sites/default/files/pdf/newsletter_noiembrie_2014.pdf *** GUS- Central Statistical Office of Poland (2001), (2006), (2013) *** World Bank' databasis. Retrieved from www.quandl.com/c/economics/industry-share-of-employment-by-country *** Ziarul Financiar (18 martie 2015) 